\title{
Sex, gut microbiome, and cardiovascular disease risk
}

Alexander C. Razavi ${ }^{1,2}$, Kaitlin S. Potts ${ }^{2}$, Tanika N. Kelly ${ }^{2}$ and Lydia A. Bazzano ${ }^{1,2^{*}}$

\begin{abstract}
Key differences exist between men and women in the determinants and manifestations of cardiovascular and cardiometabolic diseases. Recently, gut microbiome-host relations have been implicated in cardiovascular disease and associated metabolic conditions; therefore, gut microbiota may be key mediators or modulators driving the observed sexual dimorphism in disease onset and progression. While current evidence regarding pure physiological sex differences in gut microbiome composition is modest, robust research suggests that gut microbiome-dependent metabolites may interact with important biological pathways under sex hormone control, including toll-like receptor and flavin monooxygenase signaling. Here, we review key sex differences in gut microbiome interactions with four primary determinants of cardiovascular disease, impaired glucose regulation, dyslipidemia, hypertension, and obesity. Through this process, we propose important sex differences in downstream metabolic pathways that may be at the interface of the gut microbiome and cardiovascular disease.
\end{abstract}

Keywords: Gut microbiome, Cardiovascular diseases, Sex difference, Obesity, Lipids, Insulin, Blood pressure, TMAO

\section{Background}

It is increasingly appreciated that the human gut microbiome, a network that includes over 100 trillion bacteria, and its changes over the lifespan are involved in the pathophysiology of cardiovascular disease (CVD) [1-3]. For example, gut microbial-dependent metabolites including, short-chain fatty acids (SCFAs) and trimethylamine $\mathrm{N}$-oxide (TMAO), may modify CVD determinants through $G$ protein-coupled receptors (GPCR) that modulate blood pressure [4] or through inhibition of high density lipoprotein (HDL)-coordinated reverse cholesterol transport [2], respectively. The extent to whether such microbe-host physiology exhibits sexual dimorphism in the setting of CVD remains largely unexplored, as these dynamic relationships have not been clearly defined or systematically reviewed across both men and women.

This review focuses on the biological pathways underlying sex differences in CVD, particularly involving novel relationships between the gut microbiome and CVD risk factors. We will first review sex

\footnotetext{
* Correspondence: Ibazzano@tulane.edu

${ }^{1}$ Department of Medicine, Tulane University School of Medicine, New Orleans, LA, USA

${ }^{2}$ Department of Epidemiology, Tulane University School of Public Health and Tropical Medicine, 1440 Canal Street, Suite 2000, New Orleans, LA 70112, USA
}

differences regarding four primary determinants of disease including blood pressure, lipid metabolism, glucose metabolism, and body weight. We will then introduce the gut microbiome, highlighting its intricate relationship with the human diet, and discuss the downstream microbiome-dependent metabolites and pathways influencing CVD. Through this process, we will assess the current evidence regarding the relationships of the gut microbiome with blood pressure, serum lipid, and glycemic profiles, as well as body weight, and the potential influence of sexual dimorphism in these gut microbiome-host relations.

\section{Sex differences in CVD and CVD risk factors}

CVD is responsible for the greatest proportion of deaths in both men and women, with CVD mortality rates approximately $32 \%$ and $35 \%$, respectively $[5,6]$. While age-adjusted CVD mortality rates are higher in men compared to premenopausal women $[6,7]$, one third of women in the USA are affected by CVD, and nearly $50 \%$ of women in Western countries will die from coronary heart disease or stroke [8]. Furthermore, whereas clinical and public health CVD efforts must continue to target both sexes equally, key differences in the epidemiology and pathophysiology of risk factors have been identified in men and women. These 
corresponding differences underline the need to examine the role of sex in the development and progression of CVD and its respective upstream disease risk factors.

A large body of evidence has demonstrated sex differences in CVD risk over the past several decades. Impaired glucose regulation, dyslipidemia, hypertension, and obesity are among the most important CVD risk factors in the general population. Table 1 highlights fundamental biological sex differences in these four risk factors as well as the evidence and potential underlying mechanisms that may mediate such observations.

\section{Introduction to the microbiome}

The human microbiota represents the collection of microorganisms that live in and on the human body, including the gastrointestinal tract, urogenital system, and skin. The human microbiome, precisely, refers to the genomes of such microorganisms, including bacteria, fungi, archae, protists, and viruses [9]. While all five latter microorganisms are found in the human gut, bacteria are the most prevalent and well-studied, and relationships of the virome, mycobiota, and archae with human health remain largely unexplored. Microbial cells outnumber host cells in the human body, and the gut microbiome plays a critical role in host metabolism, physiology, and susceptibility to and risk of disease, particularly CVD [10]. Our gut microbiota, predominantly bacteria, helps absorb and metabolize food constituents, producing biologically active microbial metabolites that proceed through the portal system, entering systemic circulation to influence human physiology.

\section{Diet and the gut microbiome}

The gut microbiome serves as a filter for perhaps the most common human environmental exposure, diet. Our diets are one the most important modulators of microbiota composition and its respective metabolites, notably TMAO and

Table 1 Sexual dimorphism in four main cardiovascular disease risk factors

\begin{tabular}{|c|c|c|c|}
\hline CVD risk factor & Men & Women & Evidence/potential mechanisms \\
\hline $\begin{array}{l}\text { Impaired glucose } \\
\text { regulation }{ }^{A}\end{array}$ & $\begin{array}{l}\uparrow \text { Incidence of impaired fasting } \\
\text { glucose } \\
\uparrow \text { Incidence of diabetes at earlier } \\
\text { ages } \\
\downarrow \text { Insulin sensitivity }\end{array}$ & $\begin{array}{l}\uparrow \text { Incidence of impaired glucose } \\
\text { tolerance } \\
\downarrow \text { Incidence of diabetes } \\
\uparrow \text { Insulin sensitivity }\end{array}$ & $\begin{array}{l}\text { Estrogens may confer a protective effect on } \\
\text { insulin-glucose homeostasis [172-178]: } \\
\text { - Reduction in inflammation, reactive oxygen } \\
\text { species, hepatic glucose production, and } \\
\text { central and visceral adiposity. } \\
\text { - Improves glucose uptake by skeletal muscle } \\
\text { via activation of PPAR- } \gamma \text {. } \\
\text { Testosterone appears to exhibit a U-shaped } \\
\text { association with insulin resistance [179-183]: } \\
\text { - Excess testosterone in both sexes is } \\
\text { associated with dysglycemia and inhibits } \\
\text { myocyte, adipocyte insulin in women. } \\
\text { - Testosterone associates with reduced visceral } \\
\text { and central adiposity, as well as decreased } \\
\text { waist-to-hip ratio in men. }\end{array}$ \\
\hline
\end{tabular}

\begin{tabular}{|c|c|c|}
\hline Dyslipidemia $^{B}$ & $\begin{array}{l}\downarrow \mathrm{HDL}-\mathrm{C} \\
\uparrow \mathrm{LDL}-\mathrm{C} \\
\uparrow \mathrm{VLDL} \\
\uparrow \text { Total plasma TG } \\
\uparrow \mathrm{FFA} \text { oxidation at rest }\end{array}$ & $\begin{array}{l}\uparrow \mathrm{HDL}-\mathrm{C} \\
\downarrow \mathrm{LDL}-\mathrm{C} \\
\downarrow \text { VLDL } \\
\downarrow \text { Total plasma TG } \\
\uparrow \text { FFA storage at rest }\end{array}$ \\
\hline Hypertension $^{C}$ & $\begin{array}{l}\text { Younger ages }[118,188-190] \\
\uparrow \text { Systolic BP } \\
\uparrow \text { Incident hypertension } \\
\downarrow \text { Salt sensitivity } \\
\text { Older ages } \\
\downarrow \text { Incident hypertension } \\
\text { All ages } \\
\uparrow \text { Diastolic BP } \\
\downarrow \text { Survival with hypertension }\end{array}$ & $\begin{array}{l}\text { Younger ages } \\
\downarrow \text { Systolic BP } \\
\downarrow \text { Incident hypertension } \\
\uparrow \text { Salt sensitivity } \\
\text { Older ages (postmenopausal) } \\
\uparrow \text { Incident hypertension } \\
\text { All ages } \\
\downarrow \text { Diastolic BP } \\
\uparrow \text { Survival with hypertension }\end{array}$ \\
\hline Obesity $^{\mathrm{D}}$ & $\begin{array}{l}\downarrow \text { Obesity [195] } \\
\uparrow \text { Lean tissue; } \downarrow \text { Total fat } \\
\uparrow \text { Visceral adipose tissue }\end{array}$ & $\begin{array}{l}\uparrow \text { Obesity [195] } \\
\downarrow \text { Lean tissue; } \uparrow \text { Total fat } \\
\uparrow \text { Subcutaneous adipose tissue }\end{array}$ \\
\hline
\end{tabular}

Sexual dimorphism is observed in lipid profiles of premenopausal women compared to men [184-187]

Endogenous estrogen has a BP lowering effect [118, 191-194].

- Possible mechanisms include RAAS and endothelin system, oxidative stress, nitric oxide production, and salt sensitivity. Androgens (testosterone) have pro-hypertensive properties.

- Possible mechanisms include blunting of the pressure-natriuresis relationship, RAAS, and oxidative stress.

Estrogen and androgens impact energy utilization, storage, and fat distribution [196-199].

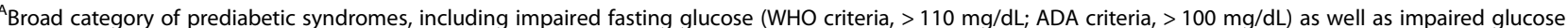
tolerance, a condition in which a given concentration of insulin, endogenous or exogenous, is accompanied by an inadequate glucose response

${ }^{\mathrm{B}}$ An elevation in circulating total cholesterol, low-density lipoprotein, high-density lipoprotein, and/or triglycerides

CDefined by ACC/AHA 2017 guidelines: systolic blood pressure $\geq 130 \mathrm{mmHg}$ or diastolic blood pressure $\geq 80 \mathrm{mmHg}$

${ }^{D}$ Defined by a body mass index $\geq 30 \mathrm{~kg} / \mathrm{m}^{2}$

$B P$ blood pressure, FFA free fatty acids, HDL-C high-density lipoprotein cholesterol, $L D L-C$ low-density lipoprotein cholesterol, $P P A R-\gamma$ peroxisome proliferatoractivator gamma, RAAS renin-angiotensin-aldosterone system, VLDL-C very low-density lipoprotein cholesterol
} 
SCFA [11]. While sex differences were not explored in the analysis, one study comparing children adherent to a rural diet in Burkina Faso (vegetarian, high fiber, low fat) versus a modernized western diet in Europe (animal protein, low fiber, high fat) found that rural children had significant increases in Bacteroidetes phyla as well as Prevotella and Xylanibacter genera and a reduction in the Firmicutes bacterial phylum [12]. Together, this microbial composition also led to a significant increased production of the three most prevalent SCFA, acetate, propionate, and butyrate. Thus, diets high in fiber and plant protein as well as low in saturated fat may lead to increased microbial richness and more abundant production of SCFA [12]. SCFAs are fermentation by-products of carbohydrates and proteins that help maintain the integrity of the intestinal brush border but may also reduce CVD risk through reductions in systolic blood pressure and serum cholesterol, as well as through improved insulin sensitivity [13, 14]. Similar to SCFA, gut microbiota-dependent metabolite, TMAO, is intricately associated with dietary intakes. TMAO has been causally associated with atherosclerosis, and this metabolite derives from foods rich in choline, phosphatidylcholine, and carnitine [11]. The latter three dietary metabolites are predominantly found in animal-based foods, including eggs, red meat, and dairy, and studies in vegetarians and vegans have confirmed that individuals adherent to plant-based diets produce less TMAO compared omnivorous to subjects [15] (Table 2). Mechanistically, dietary foods that contain TMAO metabolite substrates are converted by gut microbial enzymes to trimethylamine, which is subsequently oxidized by hepatic flavin monooxygenase 3 (FMO3) to yield TMAO [3].

Differences in dietary intake between men and women may thus be an important source of sexual dimorphism in CVD risk. While not all reports have observed sex differences in diet $[16,17]$, several studies have reported that men consume fewer high-fiber foods, including fruits and vegetables, and have higher dietary intakes of fat and salt compared to women in both childhood and adulthood [18-20]. Likewise, consistent associations have been reported between specific foods and gender, with red meat and alcohol associated with masculinity, whereas femininity has been correlated with fish, fruits, and vegetables [21]. Therefore, differences in dietary intake in men and women, perhaps stemming from societal and behavioral factors, may be important to consider when assessing the role of the gut microbiome in sexual dimorphism in CVD and its associated risk factors.

Table 2 Sexual dimorphism in four main cardiovascular disease-related metabolites

\begin{tabular}{|c|c|c|c|}
\hline Metabolite & Men & Women & Cardiovascular disease risk \\
\hline $\begin{array}{l}\text { Branched-chain amino } \\
\text { acids }\end{array}$ & $\begin{array}{l}\uparrow \text { Serum branched-chain amino } \\
\text { acids } \\
\downarrow \text { Branched-chain 2-oxoacid } \\
\text { dehydrogenase }\end{array}$ & $\begin{array}{l}\downarrow \text { Serum branched-chain amino acids } \\
\uparrow \text { Branched-chain 2-oxo acid } \\
\text { dehydrogenase }\end{array}$ & $\begin{array}{l}\text { Increased risk of insulin resistance and } \\
\text { type II diabetes in men compared to women } \\
\text { - Possible mechanisms include female sex } \\
\text { hormone regulation of branched-chain } \\
\text { 2-oxoacid dehydrogenase and enrichment } \\
\text { of the gut microbial Bacteroides-Prevotella } \\
\text { group in men }[30,72] \text {. }\end{array}$ \\
\hline Short-chain fatty acids & $\begin{array}{l}\downarrow \text { Short-chain fatty acids } \\
\downarrow \text { Dietary fiber intake } \\
\downarrow \text { PPAR- } \gamma\end{array}$ & $\begin{array}{l}\uparrow \text { Short-chain fatty acids } \\
\uparrow \text { Dietary fiber intake } \\
\uparrow \text { PPAR- } \gamma\end{array}$ & 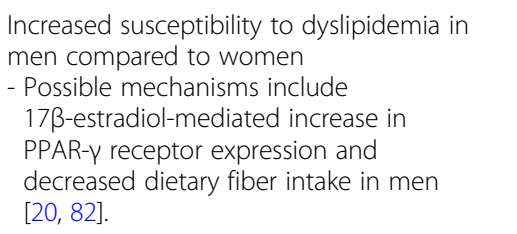 \\
\hline Trimethylamine $\mathrm{N}$-oxide & $\begin{array}{l}\downarrow \text { TLR expression } \\
\downarrow \text { FMO3 expression } \\
\downarrow \text { Secondary bile acids }\end{array}$ & $\begin{array}{l}\uparrow \text { TLR expression } \\
\uparrow \text { FMO3 expression } \\
\uparrow \text { Secondary bile acids }\end{array}$ & $\begin{array}{l}\text { Greater thrombotic risk in women compared } \\
\text { to men } \\
\text { - Possible mechanism: increased TLR and } \\
\text { trimethylamine } \mathrm{N} \text {-oxide activation of } \\
\text { platelets. }[54,55] \text {. } \\
\text { Accelerated trimethylamine } \mathrm{N} \text {-oxide } \\
\text { production } \\
\text { in women compared to men } \\
\text { - Possible mechanisms: gonadal hormone } \\
\text { regulation } \\
\text { of hepatic FMO3 expression and increased } \\
\text { secondary } \\
\text { bile acid activation of Farnesoid } X \text { receptor } \\
{[43,87] \text {. }}\end{array}$ \\
\hline Lipopolysaccharide & $\begin{array}{l}\downarrow \text { TLR4 expression } \\
\downarrow \text { TLR2 signaling }\end{array}$ & $\begin{array}{l}\uparrow \text { TLR4 expression } \\
\uparrow T L R 2 \text { signaling }\end{array}$ & $\begin{array}{l}\text { Estrogens, progesterone, and testosterone } \\
\text { regulate } \\
\text { LPS-mediated signaling through } \\
\text { TLR4 [62-64]. }\end{array}$ \\
\hline
\end{tabular}




\section{Sex differences in the microbiome}

Sexual dimorphism in the gut microbiome may be influenced by genotype, diet, age, ethnicity, geographic location, and/or the health status of the host [22]. Characterizing gut microbiome profiles through bacterial phyla [23, 24] demonstrates high proportions of Bacteroidetes and Firmicutes phyla in healthy adults, while Proteobacteria, Actinobacteria, Fusobacteria, and Verrucomicrobia are phyla less represented [25-27]. Evidence from studies suggests that women may harbor a higher ratio of Firmicutes/Bacteroidetes $(\mathrm{F} / \mathrm{B})$ in comparison to men [28-30]. The F/B ratio, increasing in magnitude from birth to adulthood [31], is used in microbiome studies as it is an important measure of human microbiota composition and appears to be a key component in biological aging and obesity [32]. Additionally, Firmicutes and Bacteroidetes are the two most common bacterial phyla in the human microbiome; therefore, perturbations in the proportional composition of these two taxonomical groups may provide insight into host health status. Bacteroidetes are the most prevalent phylum of gram-negative bacteria occupying the human gastrointestinal tract and are considered to be largely beneficial due to their functional capabilities of polysaccharide degradation and regulation of calorie absorption [33]. With respect to Firmicutes, most gut bacteria representing this phylum are gram-positive and are capable of producing several SCFAs, which may contribute to a protective CVD phenotype through improved blood pressure control and glucose homeostasis [13]. The F/B ratio is heavily influenced by BMI [34] and thus may play a significant role in regulation of adiposity. Among those with a BMI greater than 33, a significantly lower F/B ratio has been seen in men compared to women, while the opposite holds true in those with a BMI less than 33 as well as in postmenopausal women [35]. Adjusting for BMI, higher proportions of Firmicutes have been found in women compared to men. With respect to other less represented gut microbiome phyla, higher numbers of Proteobacteria, Veillonella, and Blautia have been reported in women in comparison with men $[29,35,36]$. The F/B ratio has been used as an indicator of gut dysbiosis, with a higher $\mathrm{F} / \mathrm{B}$ ratio representing a more dysbiotic microbiome.

In addition to compositional differences, sex-specific heterogeneity may exist in microbiome responses to external stimuli, including diet. In one study of Japanese individuals between 18 and 23 years of age, sex was found to modify the relationship between yogurt consumption and gut microbiome composition. Regular yogurt consumption was associated with a higher proportion of Lactobacillus casei in women yet was negatively associated with microbiome concentrations of Lactobacillus sakei, Enterobacteriaceae, and Staphylococcus in men [37]. Lactobacilli are the most common species found in probiotic preparations [38] currently being investigated for benefit in several gastrointestinal diseases, such as ulcerative colitis [39] and irritable bowel syndrome [40]. While findings from the noted research may suggest that sex biologically modifies the relationship between diet and the gut microbiome, investigators in this study did not control for important covariates including BMI or baseline diet.

Very few studies have specifically explored gut microbiome differences between men and women as a primary research question, as much of the current evidence stems from sensitivity and post hoc analyses. Additionally, while a significant body of evidence demonstrates that early infant life and age are key determinants of gut microbial composition, no prospective longitudinal studies tracking potential sex differences in the gut microbiome across the lifespan have been conducted.

\section{The microbiome and CVD risk factors: role of sex differences}

Bidirectionality is an important consideration when describing gut microbiome changes in relation to respective CVD risk factors. Dyslipidemia, dysglycemia, hypertension, and obesity may all induce or themselves be modified by gut microbiome changes [41] (Fig. 1). In spite of the prematurity of the scientific discipline and the need for longitudinal studies to establish temporality, there is a considerable amount of evidence to parse regarding sexspecific differences underlying the relationship of the gut microbiome and traditional CVD risk factors. The focus here is to highlight aspects of microbiome-CVD risk factor relationships that may be a result of or contribute to observed sex differences in disease.

Some of the evidence implicating microbiota with CVD risk factors and identifying sex differences in these relationships comes from experimental studies in mice that have used various biological mouse models. For example, apolipoprotein E-deficient mice are atherosclerosis-prone and have been used to assess the role of microbiota in atherosclerotic processes [42]. Ovariectomy and castration in female and male mice, respectively, allow for the study of hormonal influences on physiology and susceptibility to disease [43]. Germ-free mice are commonly used in microbiome-related research as they are raised in conditions that render them completely free of all (detectable) microorganisms. This offers the possibility of studying effects in the total absence of microbes (germ-free) and in the presence of known microbes (gnotobiotic) once introduced to the germ-free mice, for example after fecal transplantation. This model allows for studying the temporal and near direct effects of the gut microbiome on phenotypes, as gut microbiota are transferred from donor mice with a particular disease phenotype to recipient germ-free mice [44]. An alternative method to using germ-free mice is antibiotic treatment to depress resident microbes prior 


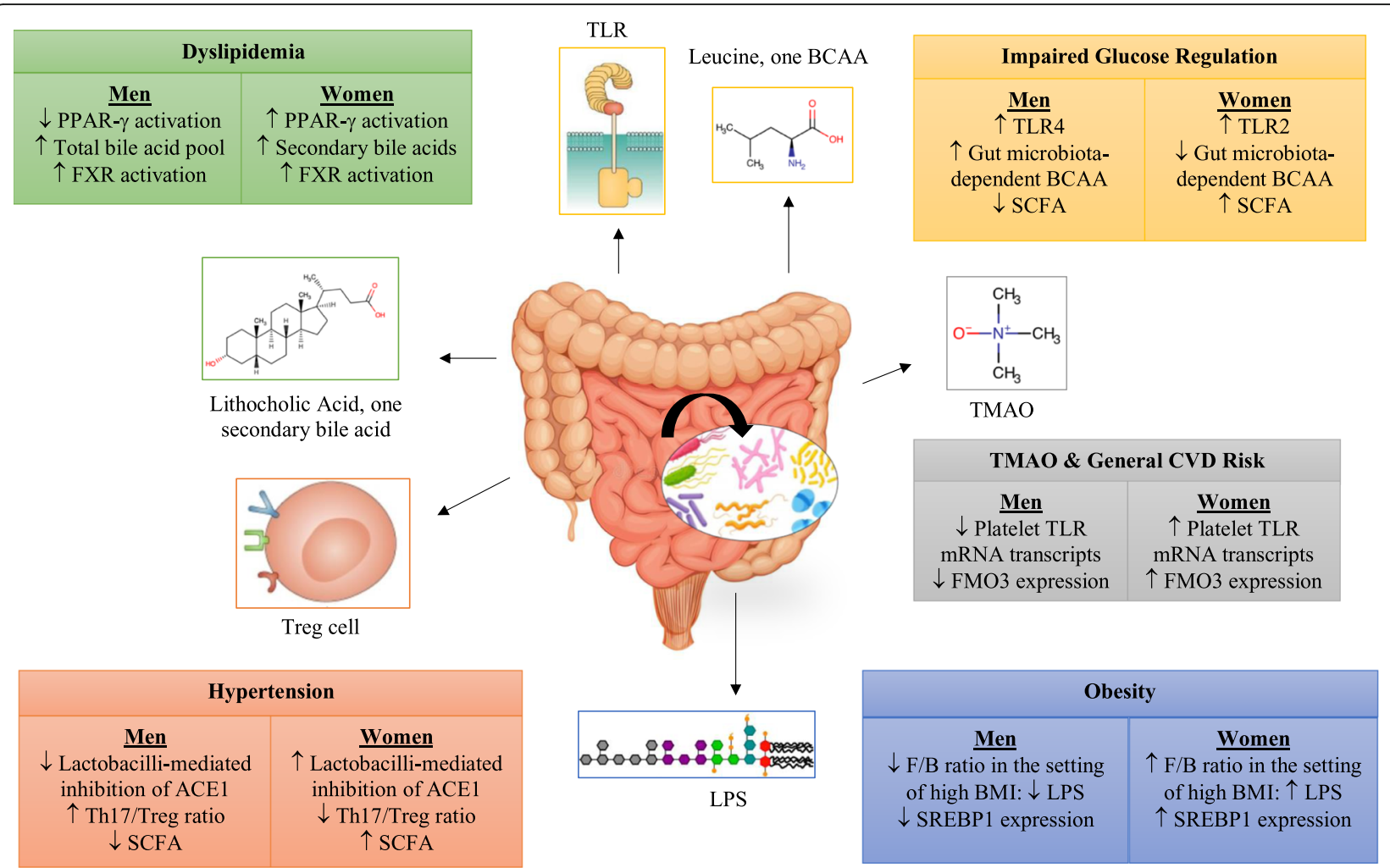

$\mathrm{ACE} 1=$ angiotensin converting enzyme $1 ; \mathrm{BCAA}=$ branched-chain amino acids; F/B=Firmicutes/Bacteroidetes ratio; FMO3=flavin monooxygenase 3; FXR=farnesoid X receptor; LPS=lipopolysaccharide; PPAR- $\gamma=$ peroxisome proliferator-activated receptor gamma; $\mathrm{SCFA}=$ short-chain fatty acid; $\mathrm{SREBP} 1=$ sterol regulatory element-binding protein 25 , $\mathrm{Th}=\mathrm{T}$ helper cell; TLR=toll-like receptor; TMAO=trimethylamine $\mathrm{N}$-oxide; Treg=regulatory $\mathrm{T}$ cell

Fig. 1 Proposed mechanisms by which gut microbiota mediate sex differences in cardiovascular disease risk

to introducing specific microbes for study [45]. Knockout mice have also been used to assess the impact of a loss of certain genes on the relationship between the microbiome and CVD risk factors [46].

\section{Microbiome and markers of cardiovascular disease risk}

Direct evidence for the involvement of the gut microbiome in the etiology of CVD comes from TMAO [47], a gut microbiome-dependent plasma metabolite that has been associated with increased CVD risk and events in several human and animal studies [47, 48]. TMAO is a prevalent metabolite in animals and humans, serving as an osmolyte particularly in the kidney, and high plasma concentrations of TMAO may suggest both underlying CVD and/or renal disease [49]. Of the metabolite's many functions, TMAO modulates cholesterol metabolism in the liver, intestines, and arterial walls. When TMAO is present in systemic circulation, there is increased accumulation and decreased removal of cholesterol from peripheral endothelial cells lining arterial walls [50]. Circulating TMAO levels trigger increases in pro-inflammatory cytokine expression, leukocyte recruitment, and adhesion molecules, inducing vascular inflammation [51]. Wang et al. were able to prevent atherosclerosis in apolipoprotein Edeficient mice by reducing plasma TMAO levels [52], and TMAO levels may predict adverse cardiovascular events [53]. Heart failure patients have increased levels of TMAO compared with age- and sex-matched controls, and elevated TMAO is also associated with shorter survival in heart failure [48]. The cardiovascular risks of varying TMAO plasma levels were transferrable by gut microbiota transplantation in antibiotic-treated mice [45].

Overall, men may harbor protective physiological mechanisms with respect to endogenous TMAO production. Sexual dimorphism in the TMAO pathway may be attributable to diet, genetics, and hormones, as well as renal and immuno-physiologic factors. TMAO increases both platelet reactivity and thrombotic risk [54]. Sex differences in TMAO-induced platelet activation may be mediated by toll-like receptors (TLR); women contain more TLR mRNA transcripts compared to men [55], potentially making them more vulnerable to the adverse cardiovascular effects of TMAO. FMO3 catalyzes the rate-limiting step in TMAO production. Sex differences in hepatic FMO3 expression have been reported, with women expressing higher levels of this TMAOproducing enzyme compared to men [43]. FMO3 may 
be under hormonal regulation, as castrated male mice experience an over 100- and 7-fold rise in FMO3 mRNA and TMAO levels, respectively [43]. Estrogen, although to a smaller magnitude than androgens, also seems to influence FMO3 expression; estrogen supplementation in ovariectomized mice increases FMO3 expression. In total, these results suggest that androgens are the primary drivers of sex differences in hepatic FMO3 expression, with estrogens complementarily widening this difference although by a much smaller magnitude. Androgen-dependent reduction in FMO3 expression is thus a potential protective factor in the setting of atherogenic CVD. Farnesoid X receptor (FXR), which plays a role in bile acid receptor signaling [56, 57], may also regulate TMAO production via FMO3. Similar rises in plasma TMAO across both sexes are noted upon synthetic FXR activation in mice [43]. Though not previously reported, we believe that FXR-induced TMAO production may partially explain the observed potential deleterious effects of FXR on CVD risk, and that microbiome-derived secondary bile acids are a possible mediator of sexual dimorphism in this pathway. Women reportedly contain higher circulating concentrations of gut microbiome-dependent secondary bile acids compared to men, and this physiological manifestation may accelerate TMAO production, subsequently increasing atherogenic and thrombotic risk.

\section{Microbiome and impaired glucose regulation}

Gut microbiome dysbiosis has been implicated in the pathogenesis of type II diabetes [41]. Individuals with type II diabetes have both functional and compositional gut microbiota differences compared to those without disease [58]. Transfer of fecal microbiota from healthy human hosts to individuals with metabolic syndrome has increased gut microbial diversity and improved insulin sensitivity [59]. Such evidence demonstrates a role for the gut microbiome in the development of glycemic dysregulation and type II diabetes; however, mechanistic pathways and sex-specific pathophysiology remain to be elucidated.

Among the number of mechanisms by which gut dysbiosis could contribute to insulin resistance, one primary means may be through systemic low-grade inflammation [60]. Inflammation can disrupt insulin sensitivity via TLR signaling cascades. Toll-like receptor 2 (TLR2) knockout mice exhibit insulin resistance and glucose intolerance associated with key modifications in intestinal microbiota, including higher proportions of Bacteroidetes and Firmicutes coupled with a lower proportion of Proteobacteria phyla [46]. Insulin resistance associated with absent TLR2 signaling may be attributed to increased serum lipopolysaccharide (LPS) activation of toll-like receptor 4 (TLR4) in the muscle, liver, and adipose tissue [61]. Sex-specific expression and signaling through both TLR2 and TLR4 have been reported [62], particularly through sex hormones. Testosterone decreases TLR4 expression in macrophages [63], and exogenous estrogen treatment in mice increases cell membrane expression of TLR4 [64], while progesterone diminishes LPS-mediated TLR4 signaling [65]. Therefore, although no studies have specifically examined the potential modifying effects of sex on the relationship between the gut microbiome and insulin resistance, sexspecific activation of inflammatory pathways is an important area for future research.

The relationship between the gut microbiome and insulin sensitivity may be modified by the serum metabolome. Serum triglycerides [66], membrane phospholipids [67], and branched-chain amino acids (BCAAs) [68] are associated with insulin resistance and type II diabetes. Gut microbiota are intricately involved in metabolite biochemical pathways, helping synthesize vitamins, SCFAs, and amino acids, but also facilitate bile acid transformation and hydrolysis of non-digestible molecules [69]. In one study of 300 Danish individuals, insulin resistance was characterized by high serum concentrations of BCAAs and high proportions of gut microbiota Prevotella copri and Bacteroides vulgatus species, which have a high biosynthetic potential for producing BCAAs [70]. Notably, sex differences have been reported in BCAA and related degradation product metabolism, with men exhibiting higher serum metabolome concentrations of BCAA compared to metabolically similar women [71]. These findings are in line with data demonstrating that the Bacteroides-Prevotella groups are more prevalent in men compared to women [30]. In an animal model, female rats have more pronounced diurnal variation in hepatic branched-chain 2-oxoacid dehydrogenase (BCODH) activity, with over a twofold increase in morning expression of $\mathrm{BCODH}$ compared to male rats [72]. BCODH facilitates the catabolism of circulating BCAAs. Female sex hormones may be responsible for BCODH diurnal variation, as gonadectomy inhibits diurnal variation in female but not male rats [72]. Given that higher serum BCAA concentrations confer increased risk for glucose abnormalities [68, 73], female sex hormone regulation of $\mathrm{BCODH}$ may confer a protective effect for insulin resistance and type II diabetes.

\section{Microbiome and lipids}

Gut microbes may affect lipid metabolism through several potential mechanisms. One biologic pathway implicated is gut microbial fermentation of non-digestible carbohydrates. Anaerobic bacteria are uniquely capable of digesting complex carbohydrates, or dietary fiber, with one primary product being SCFAs [41]. There is 
significant heterogeneity with respect to dietary fiber and SCFA production, of which butyrate, propionate, and acetate are the most abundant. In vitro studies suggest that hydrolyzed guar gums lead to the highest gut microbiota-dependent production of butyrate, while pine fiber and arabinogalactan are the major contributors to acetate and propionate production, respectively [74]. Likewise, fermentation of resistant starch, a dietary and functional fiber found in high amounts in specific foods, including banana flour and rolled oats, favors butyrate production [74]. SCFAs may affect CVD risk via a wide variety of mechanisms including lipid and glucose metabolism, as well as blood pressure modulation [75]. For example, evidence suggests that propionate prevents de novo lipogenesis and cholesterogenesis and may also reduce visceral and liver fat [76]. Such physiology may be mediated through propionate's activation of GPCR43, a receptor expressed in intestinal and adipose tissue, as well as in immune cells [77]. No sex differences were observed in one rodent study involving production of propionate in response to oligofructose-supplemented diets [78]. Butyrate and acetate have higher selectivity for GPCR41 and GPCR43, respectively, and are both metabolized to become incorporated into fatty acids and cholesterol [13]. Acetate, propionate, and butyrate may interact with peroxisome proliferator-activated receptors (PPARs) in liver, heart, and skeletal muscle tissue, increasing mitochondrial biogenesis and fatty acid oxidation that ultimately lowers lipid levels [79]. PPARs occupy a critical role in the regulation of lipid and carbohydrate metabolism, and sex differences have been reported in the stimulation of PPAR gamma [80]. Pioglitazone, a PPAR-gamma agonist, exhibits stronger efficacy in female mice compared to male mice [81]. This finding may be attributed to 17B-estradiol and a downstream increase in PPAR gamma receptor expression [82]. Besides biological sex, differences in dietary habits and/or genetics are also important variables to consider in the setting of SCFA production and lipid metabolism.

In addition to SCFA, secondary bile acids produced from colonic bacteria may regulate hepatic and systemic lipid metabolism via the bile acid receptor FXR [83]. Hepatic lipids as well as systemic total cholesterol and triglycerides are increased in mice with no expression of FXR, while FXR agonism lowers plasma lipid concentrations $[56,57]$. The clinical implication of FXR inactivation is the important role it plays in preventing dyslipidemia, but also hepatic steatosis, a disease that has been closely associated with CVD. In particular, sexspecific expression of lipid-related genes, including Fas, Colla1, Timp1, and Smpd3, may be FXR-dependent [84]. FXR knockout mice do not display sex-specific expression of lipid- and bile acid-associated genes [85], suggesting that the interaction of microbiota, bile acids, and
FXR may be partially responsible for sexual dimorphism in lipid homeostasis.

Though women have smaller bile acid pools paralleled to men [86], women produce higher concentrations of secondary bile acids compared to men [87]; therefore, perhaps, women harbor more gut microbiota that are capable of bile acid transformations. Gut bacterial species in the colon, especially Clostridum, Eubacterium, Ruminococcus, Coprococcus, Dorea, Lachnospira, Roseburia, and Butyrivibrio [88, 89], remove bile acid hydroxyl, glycine, and/or taurine groups to yield secondary bile acids that then enter the portal circulation. Secondary bile acids may then activate a number of downstream targets, including FXR, having potential mixed effects on CVD risk [90], leading to a decrease in serum triglycerides and an increase in HDL cholesterol. While an important basis for the sex-specific interplay among the gut microbiome, FXR, and bile acids has been identified, further research is required to explain how these factors subsequently modify lipid-related risk of CVD.

In addition to bile acids, cholesterol-derived steroid hormones may hold an important relationship with gut microbiota in the setting of CVD. Male mice have lower gut microbiome diversity compared to female mice in the same environment $[44,91,92]$, and this difference is reduced upon the gonadectomy of male mice. Similarly, animal models demonstrate that gut microbiota are vital in supporting regular estrogen cycles, testosterone concentration, and reproductive roles in men and women [9193]. Gut bacteria may facilitate the reabsorption of conjugated estrogens, as antibiotic administration has been associated with a 60-fold rise in conjugated estrogen excretion in feces [94, 95]. Bacterial beta-glucuronidase is the primary enzyme involved in deconjugating estrogens for reabsorption in the intestines [96], and the genes encoding this protein are primarily found in the Firmicutes phylum [97, 98]. Though levels of Firmicutes appear to be influenced by body weight, women may harbor higher intestinal Firmicutes compared to men irrespective of BMI [35]. These results suggest that gut microbiota may play a role in key steroid hormone changes across the lifespan that underlie CVD risk, for example, the menopausal estrogen decline and consequent proatherogenic shift of lipid profiles in women.

\section{Microbiome and blood pressure}

The gut microbiota has been implicated in hypertension in both animal and human studies [99-102]. High blood pressure is associated with gut microbiota dysbiosis [103], and the hypertensive phenotype is transferable from humans to germ-free mice through gut microbiota via fecal transplantation [104]. Decreased diversity of gut microbiota has been found in prehypertensive and hypertensive patients [103, 104]. Gut-derived SCFAs, prebiotics, and probiotics have all 
shown potential to decrease both systolic and diastolic blood pressure in humans $[105,106]$.

Microbiota production of SCFAs appears to play a pivotal role in the relationship between the microbiome and hypertension. Recent evidence suggests that the blood pressure lowering effects of a high-fiber (prebiotic) diet may act through the production of SCFA acetate by increasing acetate-producing bacteria in the gut [105]. Another study utilizing two independent mouse models found that the SCFA propionate reduced hypertension acting through reduced systemic inflammation via $\mathrm{T}$ cell regulation, and resulted in decreased aortic atherosclerotic lesions [107]. Although sex differences were not explored in these studies, differential intake of fiber between men and women may contribute to sexual dimorphism in hypertension, mediated by gut microbiota-dependent SCFA.

Regarding particular bacterial strains, Lactobacilli seems to be the most beneficial gut bacteria and has been linked to the antihypertensive effect of foods such as blueberries [108], fermented milk [109], and other probiotics. It should be noted that probiotics have a smaller impact on blood pressure reduction than prebiotic fiber-rich diets acting through increased SCFA production, as described above [105]. The blood pressure-lowering mechanism of Lactobacilli may be partially through secretion of peptides that inhibit angiotensin-converting enzyme [99, 110], resulting in decreased ability to convert angiotensin I to angiotensin II, a strong vasoconstrictor. Given that women have been found to have higher levels of Lactobacilli in the gut [37], this may partly explain observed lower blood pressure in women prior to menopause compared to men. In addition, men show larger increases in blood pressure in response to angiotensin II than women [111, 112 ], adding to the potential sex-differential blood pressure effects of varying gut microbiota composition.

The microbiome also acts on hypertension through immune response and inflammation. Gut dysbiosis is shown to lead to increased inflammation, and hypertension is associated with gut dysbiosis, with increased F/B ratio and altered SCFA production [113]. As described previously, the mechanism through which the gut-derived SCFA propionate delivers antihypertensive effects is partly explained by anti-inflammatory immune responses [107]. With further study, these immune-related processes may reveal gut microbiome contributions to sex differences in hypertension. Pro-inflammatory $\mathrm{T}$ helper $\left(\mathrm{T}_{\mathrm{H}}\right) 17$ cells are released from actions by gut microbiota [114] and help initiate arterial hypertension $[115,116]$, and hypertensive male rats have been found to have more $\mathrm{T}_{\mathrm{H}} 17$ cells compared to female rats [112]. Additionally, high salt diets can deplete microbiota diversity, particularly the Lactobacilli strain as demonstrated in mice and humans by Wilck et al. [117]. This Lactobacilli reduction resulted in increased $\mathrm{T}_{\mathrm{H}} 17$ cells [117]. These findings pose the possibility that higher blood pressure salt sensitivity seen in women [118] may be influenced by reduction in Lactobacilli under high-salt environments. Since women may have more Lactobacilli than men to begin with [37] and men have a higher number of $\mathrm{T}_{\mathrm{H}} 17$ cells [112], the depletion of the protective strain in women may be of greater magnitude and consequence, resulting in a larger relative increase in $\mathrm{T}_{\mathrm{H}} 17$ cells and a corresponding greater blood pressure effect.

More generally, inflammation has been identified as both a cause and a consequence of hypertension [119] and reduced microbiome diversity can lead to low-grade inflammation [120]. Estrogens can reduce inflammation [121-124], and this activity has been linked to sex differences in the gut microbiome of mice [125].

Gut microbiota production of SCFAs $[126,127]$ impacts renal sensory nerves and blood pressure [128, 129]. SCFAs, including lactate, acetate, butyrate, and propionate, produced by gut microbiota impact vasodilation and vasoconstriction by acting on cell surface receptors GPCR43, GPCR41, and olfactory receptor 78 [99]. Sex differences in renal functions that regulate blood pressure $[130,131]$ may be derived in part from microbiome variations.

Recent compelling evidence for the role of the gut microbiome in hypertension comes from a study by Menni et al. that found an inverse association between gut microbial diversity and arterial stiffness, as measured via pulse wave velocity, in women [132]. This association was mostly independent of other metabolic syndrome markers. Further evidence is needed to determine if this effect is similar for men or if this could be a factor contributing to sex differences in hypertension.

\section{Microbiome and obesity}

The gut microbiome has been implicated in the etiology of obesity, particularly through energy extraction [133] as well as energy expenditure $[99,134]$. At the same time, obesity alters the composition of the gastrointestinal microbiota $[34,35,135,136]$, indicating a bidirectional relationship.

It is known that diet modulates the composition of gut microbiota in humans and other animals [12, 120, 137142], but these changes are not easily characterized and can vary greatly by individual [143]. The composition of the gut microbiome responds quickly to large alterations in diet, but it is predominantly influenced by long-term dietary habits [143]. Sex-specific diet preferences, including different macronutrient intakes, are likely strong contributors to sex differences in the microbiome that influence obesity and other metabolic risk factors.

Differential diets result in alterations in microbiome composition as evidenced by the lower F/B ratio, with a higher proportion of Bacteroidetes phylum, in people consuming more plant-based fibers compared to those 
consuming a western diet $[12,144]$. The $\mathrm{F} / \mathrm{B}$ ratio has demonstrated sex- and BMI-dependent differences such that women have a higher F/B ratio, indicative of gut dysbiosis, at high BMI (>33) compared to men [35]. It has also been shown that the F/B ratio is higher, with increased genera in the Firmicutes phylum, in overweight and obese subjects [34, 135, 136]. Firmicutes are believed to be important in the development of obesity, and weight loss among obese subjects corresponds with a reduction in total Firmicutes such that the F/B ratio realigns with that seen in lean patients [133, 136]. The compositional microbiota differences confer the ability of microbiota in obese individuals to extract more calories from food than microbiota from lean subjects by encoding enzymes that break down otherwise indigestible polysaccharides [133] leading to increased release of LPS endotoxins into circulation. These LPS endotoxins in turn influence fat storage and adipose tissue inflammation in the progression towards obesity [145]. Given this mechanism, the increased proportions of Firmicutes that women experience in the presence of obesity indicate a possible mechanism for microbiota in the sexual dimorphism of obesity. Further evidence for the role of gut microbiota in energy harvest is seen in late-stage pregnancy where altered microbiota results in higher energy-yielding communities, increasing the capacity for energy harvest from dietary sources [146, 147].

Gut microbiota-produced SCFAs promote storage of triglycerides [148] through the activation of lipogenic liver enzymes including sterol response element binding protein-1 (SREBP-1) [149]. Compared to men, women may express higher levels of SREBP-1 [150], presenting a possible route for increased lipid storage and increased risk of obesity in women via a microbiota involved pathway. SCFAs also act on obesity development via suppression of the fastinginduced adipocyte factor (FIAF)/angiopoietin-like protein, an important inhibitor of lipoprotein lipase (LPL), as demonstrated in mice gut microbiota $[149,151]$. The resulting increased LPL corresponds to a microbiota-mediated increase in fat storage [149] that may be part of the sex difference in body composition and obesity.

In addition to energy homeostasis, the microbiome impacts chronic low-grade inflammation through a variety of mechanisms including the expression of GPR41 and GPR43 activated by gut-produced SCFAs [152] and increases in endocannabinoid system tone [153, 154]. Some mice studies have implicated GPR41 and GPR43 in the chronic inflammatory states of obesity, but the evidence is conflicting [77]. Sex-differential response to GPR41, which is also involved in regulation of energy homeostasis [155], may be an important microbiotaoriginating mechanism for sexual dimorphism in body weight. Decreased energy expenditure and increased body fat mass were reported in male but not female
GPR41 knockout mice compared to their wild littermates [156].

Despite these findings, the role of SCFAs in obesity is still unclear as evinced by studies of acetate, the most abundantly circulating SCFA in humans [157]. Several animal [152, 158-164] and some human [165-168] studies have shown beneficial effects of increased dietary sources of acetate and corresponding stimulation of microbial acetate production. These benefits include weight homeostasis influenced by satiety and appetite control $[158,160]$, resistance to weight gain and adiposity in the presence of a high fat diet $[152,163]$, and improving glucose regulation and insulin sensitivity [163]. However, recent rodent trials have also demonstrated opposite effects, finding that increased acetate turnover, resulting in part from gut microbiota acetate production, can contribute to obesity via weight gain and insulin resistance [169-171]. The role of sex differences in these processes is not established, but these discrepant findings point to the complexity and uncertainty of the role of microbiota-produced SCFAs in obesity development that needs to be considered when evaluating the role of the gut microbiome in obesity and CVD risk factors more generally.

Although evidence is mounting for the microbiota as a mediator of diet on obesity and other metabolic diseases [143], additional longitudinal research in humans is needed to elucidate the complex interplay and directionality of the microbiota-obesity relationship as well as to understand the influence of and resultant sex differences in these processes.

\section{Future directions and conclusion}

Recent investigations have highlighted key sex differences with respect to CVD prevalence, risk, and progression that may be driven by traditional risk factors including dyslipidemia, hypertension, insulin resistance, and obesity. Furthermore, while preliminary research has implicated a potential role of the microbiome in mediating the relationships of upstream risk factors and CVD, sexual dimorphism in this research area remains largely unexplored. Future studies must clearly isolate the role of sex from diet, host health, age, ethnicity, and environment to conclusively identify potential biological sex differences in the gut microbiome. In particular, prospective study designs are necessary to document temporal changes in the gut microbiome as they relate to physiological hormonal cycles and critical hormonal time periods that associate with determinants of CVD, including puberty and menopause. Initial studies suggest that microbiome-associated toll-like receptor signaling cascades, bile acid metabolism, and steroid hormone modulation may be important drivers in sex differences in CVD risk. Additional mechanistic studies are necessary to discover how gut microbiota may initiate or mediate key sex-specific 
biological determinants of CVD, particularly through the serum metabolome, in the general population. Future evidence derived from mechanistic studies may pave the way for potential low risk interventions involving microbiota to reduce CVD risk throughout the lifespan.

\section{Acknowledgements}

We would like to thank the Biology of Sex Differences journal and team for the invitation to present, discuss, and review research related to sexual dimorphism in the gut microbiome and cardiovascular disease.

\section{Authors' contributions}

$A C R, K S P, T N K$, and $L A B$ have abided by the publication and authorship rules of The Biology of Sex Differences journal. ACR, KSP, TNK, and LAB discussed the physiologic framework and outline of the manuscript. ACR, KSP, TNK, and $L A B$ wrote and revised the manuscript, as well as approved the submitted version.

\section{Authors' information}

$L A D, M D, P h D$, is the Director of the Center for Lifespan Epidemiology Research at Tulane University School of Public Health and Tropical Medicine. TNK, PhD, MPH, is an Associate Professor at Tulane University School of Public Health and Tropical Medicine, Department of Epidemiology. ACR is an MD-PhD student at Tulane University School of Medicine and Tulane University School of Public Health and Tropical Medicine, Department of Epidemiology.

KSP is a PhD student at Tulane University School of Public Health and Tropical Medicine, Department of Epidemiology

\section{Funding}

This research was supported by several grants. LAD was supported in part by the National Institute of Health under grant numbers K12HD043451, P20GM109036, R21AG057983, R01HL121230, and R01DK091718. TNK was supported in part by the National Institute of Health under grant numbers P20GM109036 and R21AG051914. ACR is currently supported through a predoctoral institutional training grant supported by the National Institute of Health under grant number 5TL1TR001418-04.

\section{Availability of data and materials}

All data analyzed during this review article are included in this published manuscript in-text or cited with a reference to the data source.

\section{Ethics approval and consent to participate}

Not applicable.

\section{Consent for publication}

Not applicable.

\section{Competing interests}

The authors declare that they have no competing interests.

Received: 31 January 2019 Accepted: 13 May 2019

Published online: 10 June 2019

\section{References}

1. Ahmadmehrabi S, Tang WHW. Gut microbiome and its role in cardiovascular diseases. Curr Opin Cardiol. 2017;32(6):761.

2. Wang Z, Klipfell E, Bennett BJ, Koeth R, Levison BS, Dugar B, et al. Gut flora metabolism of phosphatidylcholine promotes cardiovascular disease. Nature. 2011:472(7341):57.

3. Tang WHW, Wang Z, Levison BS, Koeth RA, Britt EB, Fu X, et al. Intestinal Microbial Metabolism of Phosphatidylcholine and Cardiovascular Risk. N Engl J Med. 2013;368(17):1575-84

4. Natarajan N, Hori D, Flavahan S, Steppan J, Flavahan NA, Berkowitz DE, et al. Microbial short chain fatty acid metabolites lower blood pressure via endothelial G protein-coupled receptor 41. Physiol Genomics. 2016;48(11):826-34.

5. Zhou M, Wang H, Zhu J, Chen W, Wang L, Liu S, Li Y, Wang L, Liu Y, Yin P, Liu J. Cause-specific mortality for 240 causes in China during 1990-2013: a systematic subnational analysis for the Global Burden of Disease Study 2013. Lancet. 2016;387(10015):251-72.
6. Mosca L, Barrett-Connor E, Kass Wenger N. Sex/gender differences in cardiovascular disease prevention: what a difference a decade makes. Circulation. 2011;124(19):2145-54.

7. Kuznetsova T. Sex differences in epidemiology of cardiac and vascular disease, In Sex-Specific Analysis of Cardiovascular Function. Cham: Springer; 2018. p. 61-70.

8. Allender S, Scarborough P, Peto V, Rayner M, Leal J, Luengo-Fernandez R, Gray A. European cardiovascular disease statistics. Eur Heart Netw. 2008:3:11-35.

9. Dobbins JJ. Prescott's microbiology. J Microbiol Biol Educ. 2010;11(1):64.

10. Sender R, Fuchs S, Milo R. Are we really vastly outnumbered? Revisiting the ratio of bacterial to host cells in humans. Cell. 2016;164(3):337-40.

11. Tang WW, Hazen SL. The gut microbiome and its role in cardiovascular diseases. Circulation. 2017;135(11):1008-10.

12. De Filippo C, Cavalieri D, Di Paola M, Ramazzotti M, Poullet JB, Massart S, Collini S, Pieraccini G, Lionetti P. Impact of diet in shaping gut microbiota revealed by a comparative study in children from Europe and rural Africa. Proc Natl Acad Sci. 2010:107(33):14691-6.

13. den Besten G, van Eunen K, Groen AK, Venema K, Reijngoud DJ, Bakker BM. The role of short chain fatty acids in the interplay between diet, gut microbiota, and host energy metabolism. J Lipid Res. 2013;54(9):2325-40.

14. Mariño E, Richards JL, McLeod KH, Stanley D, Yap YA, Knight J, McKenzie C, Kranich J, Oliveira AC, Rossello FJ, Krishnamurthy B. Gut microbial metabolites limit the frequency of autoimmune $T$ cells and protect against type 1 diabetes. Nat Immunol. 2017;18(5):552.

15. Koeth RA, Wang Z, Levison BS, Buffa JA, Org E, Sheehy BT, Britt EB, Fu X, Wu $Y$, Li L, Smith JD. Intestinal microbiota metabolism of L-carnitine, a nutrient in red meat, promotes atherosclerosis. Nat Med. 2013;19(5):576.

16. Kennedy ET, Bowman SA, Powell R. Dietary-fat intake in the US population. J Am Coll Nutr. 1999:18(3):207-12.

17. Subar AF, Thompson FE, Kipnis V, Midthune D, Hurwitz P, McNutt S, McIntosh A, Rosenfeld S. Comparative validation of the Block, Willett, and National Cancer Institute food frequency questionnaires: the Eating at America's Table Study. Am J Epidemiol. 2001;154(12):1089-99.

18. Shimakawa T, Sorlie P, Carpenter MA, Dennis B, Tell GS, Watson R, Williams OD. Dietary intake patterns and sociodemographic factors in the Atherosclerosis Risk in Communities Study. Prev Med. 1994:23(6):769-80.

19. Neumark-Sztainer D, Story M, Resnick MD, Blum RW. Lessons learned about adolescent nutrition from the Minnesota Adolescent Health Survey. J Am Diet Assoc. 1998;98(12):1449-56.

20. Imamura F, Renata M, Shahab K, Saman F, Peilin S, John P, Dariush M. Global Burden of Diseases Nutrition and Chronic Diseases Expert Group (NutriCoDE. "Dietary quality among men and women in 187 countries in 1990 and 2010: a systematic assessment." Lancet Glob. Health. 2015; 3(3):e132-42.

21. Prättälä R, Paalanen L, Grinberga D, Helasoja V, Kasmel A, Petkeviciene J. Gender differences in the consumption of meat, fruit and vegetables are similar in Finland and the Baltic countries. Eur J Pub Health. 2006;17(5):520-5.

22. Yatsunenko T, Rey FE, Manary MJ, Trehan I, Dominguez-Bello MG, Contreras M, Magris M, Hidalgo G, Baldassano RN, Anokhin AP, Heath AC. Human gut microbiome viewed across age and geography. Nature. 2012:486(7402):222

23. Barrett KE, Malley J, Naglieri C. Gastrointestinal physiology. New York: Mcgraw-hill; 2006

24. Huttenhower C, Gevers D, Knight R, Abubucker S, Badger JH, Chinwalla AT, Creasy HH, Earl AM, FitzGerald MG, Fulton RS, Giglio MG. Structure, function and diversity of the healthy human microbiome. Nature. 2012;486(7402):207.

25. Hollister EB, Gao C, Versalovic J. Compositional and functional features of the gastrointestinal microbiome and their effects on human health. Gastroenterology. 2014;146(6):1449-58.

26. Eckburg PB, Bik EM, Bernstein CN, Purdom E, Dethlefsen L, Sargent M, Gill $\mathrm{SR}$, Nelson KE, Relman DA. Diversity of the human intestinal microbial flora. Science. 2005;308(5728):1635-8

27. Quigley EM. Gut bacteria in health and disease. Gastroenterol Hepatol. 2013;9(9):560.

28. Dominianni C, Sinha R, Goedert JJ, Pei Z, Yang L, Hayes RB, Ahn J. Sex, body mass index, and dietary fiber intake influence the human gut microbiome. PloS one. 2015;10(4):e0124599.

29. Li M, Wang B, Zhang M, Rantalainen M, Wang S, Zhou H, Zhang Y, Shen J, Pang $X$, Zhang M, Wei H. Symbiotic gut microbes modulate human metabolic phenotypes. Proc Natl Acad Sci. 2008;105(6):2117-22. 
30. Mueller S, Saunier K, Hanisch C, Norin E, Alm L, Midtvedt T, Cresci A Silvi S, Orpianesi C, Verdenelli MC, Clavel T. Differences in fecal microbiota in different European study populations in relation to age, gender, and country: a cross-sectional study. Appl. Environ. Microbiol. 2006;72(2):1027-33.

31. Mariat $D$, Firmesse $O$, Levenez F, Guimarăes VD, Sokol H, Doré J, Corthier $G$, Furet JP. The Firmicutes/Bacteroidetes ratio of the human microbiota changes with age. BMC Microbiol. 2009;9(1):123.

32. Indiani CM, Rizzardi KF, Castelo PM, Ferraz LF, Darrieux M, Parisotto TM. Childhood obesity and Firmicutes/Bacteroidetes ratio in the gut microbiota: a systematic review. Child Obes. 2018;14(8):501-9.

33. Wexler HM. Bacteroides: the good, the bad, and the nitty-gritty. Clin Microbiol Rev. 2007;20(4):593-621.

34. Kasai C, Sugimoto K, Moritani I, Tanaka J, Oya Y, Inoue H, Tameda M, Shiraki K, Ito M, Takei Y, Takase K. Comparison of the gut microbiota composition between obese and non-obese individuals in a Japanese population, as analyzed by terminal restriction fragment length polymorphism and nextgeneration sequencing. BMC Gastroenterol. 2015;15(1):100.

35. Haro C, Rangel-Zúñiga OA, Alcalá-Díaz JF, Gómez-Delgado F, Pérez-Martínez P, Delgado-Lista J, Quintana-Navarro GM, Landa BB, Navas-Cortés JA, TenaSempere $\mathrm{M}$, Clemente JC. Intestinal microbiota is influenced by gender and body mass index. PloS one. 2016;11(5):e0154090.

36. Schnorr SL, Candela M, Rampelli S, Centanni M, Consolandi C, Basaglia G, Turroni S, Biagi E, Peano C, Severgnini M, Fiori J. Gut microbiome of the Hadza hunter-gatherers. Nat Commun. 2014;5:3654.

37. Suzuki Y, Ikeda K, Sakuma K, Kawai S, Sawaki K, Asahara T, Takahashi T, Tsuji H, Nomoto K, Nagpal R, Wang C. Association between yogurt consumption and intestinal microbiota in healthy young adults differs by host gender. Front Microbiol. 2017;8:847

38. Inglin RC. Combined Phenotypic-Genotypic Analyses of the Genus Lactobacillus and Selection of Cultures for Biopreservation of Fermented Food. PhD diss., ETH Zurich, 2017.

39. Zocco MA, Dal Verme LZ, Cremonini F, Piscaglia AC, Nista EC, Candelli M, Novi M, Rigante D, Cazzato IA, Ojetti V, Armuzzi A. Efficacy of Lactobacillus $\mathrm{GG}$ in maintaining remission of ulcerative colitis. Aliment Pharmacol Ther. 2006;23(11):1567-74.

40. Saggioro A. Probiotics in the treatment of irritable bowel syndrome. J Clin Gastroenterol. 2004:38:S104-6.

41. Jovel J, Dieleman LA, Kao D, Mason AL, Wine E. The Human Gut Microbiome in Health and Disease. In: Metagenomics: Academic Press; 2018. p. 197-213

42. Sasso GL, Schlage WK, Boué S, Veljkovic E, Peitsch MC, Hoeng J. The Apoe-/- mouse model: a suitable model to study cardiovascular and respiratory diseases in the context of cigarette smoke exposure and harm reduction. J Transl Med. 2016;14(1):146.

43. Bennett BJ, de Aguiar Vallim TQ, Wang Z, Shih DM, Meng Y, Gregory J, Allayee H, Lee R, Graham M, Crooke R, Edwards PA. Trimethylamine-N-oxide, a metabolite associated with atherosclerosis, exhibits complex genetic and dietary regulation. Cell Metab. 2013: 17(1):49-60.

44. Wang JJ, Wang J, Pang XY, Zhao LP, Tian L, Wang XP. Sex differences in colonization of gut microbiota from a man with short-term vegetarian and inulin-supplemented diet in germ-free mice. Sci Rep. 2016:6:36137

45. Gregory JC, Buffa JA, Org E, Wang Z, Levison BS, Zhu W, Wagner MA, Bennett BJ, Li L, DiDonato JA, Lusis AJ. Transmission of atherosclerosis susceptibility with gut microbial transplantation. J Biol Chem. 2015;290(9): 5647-60.

46. Caricilli AM, Picardi PK, de Abreu LL, Ueno M, Prada PO, Ropelle ER, Hirabara SM, Castoldi Â, Vieira P, Camara NO, Curi R. Gut microbiota is a key modulator of insulin resistance in TLR 2 knockout mice. PLoS Biol. 2011;9(12):e1001212

47. Wang Z, Klipfell E, Bennett BJ, Koeth R, Levison BS, DuGar B, Feldstein $A E$, Britt EB, Fu X, Chung YM, Wu Y. Gut flora metabolism of phosphatidylcholine promotes cardiovascular disease. Nature. 2011 Apr;472(7341):57

48. Li XS, Obeid S, Klingenberg R, Gencer B, Mach F, Räber L, Windecker S, Rodondi N, Nanchen D, Muller O, Miranda MX. Gut microbiotadependent trimethylamine $\mathrm{N}$-oxide in acute coronary syndromes: a prognostic marker for incident cardiovascular events beyond traditional risk factors. Eur Heart J. 2017;38(11):814-24.
49. Tomlinson JA, Wheeler DC. The role of trimethylamine $\mathrm{N}$-oxide as a mediator of cardiovascular complications in chronic kidney disease. Kidney Int. 2017;92(4):809-15.

50. Janeiro M, Ramírez M, Milagro, Martínez J, Solas M. Implication of trimethylamine $\mathrm{N}$-Oxide (TMAO) in disease: potential biomarker or new therapeutic target. Nutrients. 2018;10(10):1398.

51. Seldin MM, Meng Y, Qi H, Zhu W, Wang Z, Hazen SL, Lusis AJ, Shih DM. Trimethylamine $\mathrm{N}$-oxide promotes vascular inflammation through signaling of mitogen-activated protein kinase and nuclear factor-kB. J Am Heart Assoc. 2016;5(2):e002767.

52. Wang Z, Roberts AB, Buffa JA, Levison BS, Zhu W, Org E, Gu X, Huang Y, Zamanian-Daryoush M, Culley MK, DiDonato AJ. Non-lethal inhibition of gut microbial trimethylamine production for the treatment of atherosclerosis. Cell. 2015;163(7):1585-95.

53. Qi J, Tao Y, Li J, Tingting $P$, Li X, Yue H, Li Z. Circulating trimethylamine $\mathrm{N}$-oxide and the risk of cardiovascular diseases: a systematic review and meta-analysis of 11 prospective cohort studies. J Cell Mol Med. 2018;22(1):185-94.

54. Zhu W, Gregory JC, Org E, Buffa JA, Gupta N, Wang Z, Li L, Fu X, Wu $Y$, Mehrabian M, Sartor RB. Gut microbial metabolite TMAO enhances platelet hyperreactivity and thrombosis risk. Cell. 2016;165(1):111-24.

55. Koupenova M, Mick E, Mikhalev E, Benjamin EJ, Tanriverdi K, Freedman JE. Sex differences in platelet toll-like receptors and their association with cardiovascular risk factors. Arterioscler Thromb Vasc Biol. 2015;35(4):1030-7.

56. Sinal CJ, Tohkin M, Miyata M, Ward JM, Lambert G, Gonzalez FJ. Targeted disruption of the nuclear receptor FXR/BAR impairs bile acid and lipid homeostasis. Cell. 2000;102(6):731-44.

57. Watanabe M, Houten SM, Wang L, Moschetta A, Mangelsdorf DJ, Heyman RA, Moore DD, Auwerx J. Bile acids lower triglyceride levels via a pathway involving FXR, SHP, and SREBP-1C. J Clin Invest. 2004;113(10):1408-18.

58. Upadhyaya S, Banerjee G. Type 2 diabetes and gut microbiome: at the intersection of known and unknown. Gut Microbes. 2015;6(2):85-92.

59. Kootte RS, Levin E, Salojärvi J, Smits LP, Hartstra AV, Udayappan SD, Hermes G, Bouter KE, Koopen AM, Holst JJ, Knop FK. Improvement of insulin sensitivity after lean donor feces in metabolic syndrome is driven by baseline intestinal microbiota composition. Cell Metab. 2017:26(4):611-9.

60. Caricilli A, Saad M. The role of gut microbiota on insulin resistance. Nutrients. 2013;5(3):829-51.

61. Creely SJ, McTernan PG, Kusminski CM, Fisher FM, Da Silva NF, Khanolkar M, Evans M, Harte AL, Kumar S. Lipopolysaccharide activates an innate immune system response in human adipose tissue in obesity and type 2 diabetes. Am J Phy Endocrinol Metab. 2007;292(3):E740-7.

62. Roberts BJ, Moussawi M, Huber SA. Sex differences in TLR2 and TLR4 expression and their effect on coxsackievirus-induced autoimmune myocarditis. Exp Mol Pathol. 2013;94(1):58-64.

63. Rettew JA, Huet-Hudson YM, Marriott I. Testosterone reduces macrophage expression in the mouse of toll-like receptor 4, a trigger for inflammation and innate immunity. Biol Reprod. 2008;78(3):432-7.

64. Rettew JA, Huet YM, Marriott I. Estrogens augment cell surface TLR4 expression on murine macrophages and regulate sepsis susceptibility in vivo. Endocrinology. 2009;150(8):3877-84.

65. Lei B, Mace B, Dawson HN, Warner DS, Laskowitz DT, James ML. Antiinflammatory effects of progesterone in lipopolysaccharide-stimulated BV-2 microglia. PloS one. 2014;9(7):e103969.

66. Rhee EP, Cheng S, Larson MG, Walford GA, Lewis GD, McCabe E, Yang E, Farrell L, Fox CS, O'Donnell CJ, Carr SA. Lipid profiling identifies a triacylglycerol signature of insulin resistance and improves diabetes prediction in humans. J Clin Invest. 2011;121(4):1402-11.

67. Floegel A, Stefan N, Yu Z, Mühlenbruch K, Drogan D, Joost HG, Fritsche A, Häring $\mathrm{HU}$, de Angelis MH, Peters A, Roden M. Identification of serum metabolites associated with risk of type 2 diabetes using a targeted metabolomic approach. Diabetes. 2013;62(2):639-48.

68. Wang TJ, Larson MG, Vasan RS, Cheng S, Rhee EP, McCabe E, Lewis GD, Fox CS, Jacques PF, Fernandez C, O'donnell CJ. Metabolite profiles and the risk of developing diabetes. Nat Med. 2011;17(4):448

69. Xu J, Gordon Jl. Honor thy symbionts. Proc Natl Acad Sci. 2003; 100(18):10452-9.

70. Pedersen HK, Gudmundsdottir V, Nielsen HB, Hyotylainen T, Nielsen T, Jensen BA, Forslund K, Hildebrand F, Prifti E, Falony G, Le Chatelier E. Human gut microbes impact host serum metabolome and insulin sensitivity. Nature. 2016;535(7612):376. 
71. Krumsiek J, Mittelstrass K, Do KT, Stückler F, Ried J, Adamski J, Peters A, Illig T, Kronenberg F, Friedrich N, Nauck M. Gender-specific pathway differences in the human serum metabolome. Metabolomics. 2015;11(6):1815-33.

72. Kobayashi R, Shimomura Y, Murakami T, Nakai N, Fujitsuka N, Otsuka M, Arakawa N, POPOV MK, HARRIS AR. Gender difference in regulation of branched-chain amino acid catabolism. Biochemical Journal. 1997 Oct 15;327(2):449-53.

73. Xie G, Ma X, Zhao A, Wang C, Zhang Y, Nieman D, Nicholson JK, Jia W, Bao $Y$, Jia W. The metabolite profiles of the obese population are genderdependent. J Proteome Res. 2014;13(9):4062-73.

74. Pylkas AM, Juneja LR, Slavin JL. Comparison of different fibers for in vitro production of short chain fatty acids by intestinal microflora. J Med Food. 2005;8(1):113-6.

75. Morrison DJ, Preston T. Formation of short chain fatty acids by the gut microbiota and their impact on human metabolism. Gut Microbes. 2016;7(3):189-200

76. Cummings $J H$, Rombeau $J$, Sakata T, eds. Physiological and clinical aspects of short-chain fatty acids: Cambridge University Press; 2004.

77. Ang Z, Ding JL. GPR41 and GPR43 in obesity and inflammation-protective or causative? Front Immunol. 2016;7:28.

78. Falony G, Vlachou A, Verbrugghe K, De Vuyst L. Cross-feeding between Bifidobacterium longum BB536 and acetate-converting, butyrate-producing colon bacteria during growth on oligofructose. Appl. Environ. Microbio. 2006;72(12):7835-41.

79. Grygiel-Górniak B. Peroxisome proliferator-activated receptors and their ligands: nutritional and clinical implications-a review. Nutr J. 2014;13(1):17.

80. Sato $H$, Sugai $H$, Kurosaki H, Ishikawa M, Funaki A, Kimura $Y$, Ueno K. The effect of sex hormones on peroxisome proliferator-activated receptor gamma expression and activity in mature adipocytes. Biol Pharm Bull. 2013;36(4):564-73.

81. Park HJ, Park HS, Lee JU, Bothwell AL, Choi JM. Gender-specific differences in PPARY regulation of follicular helper T cell responses with estrogen. SC Rep. 2016;6:28495.

82. Han L, Wang P, Zhao G, Wang H, Wang M, Chen J, Tong T. Upregulation of SIRT1 by $17 \beta$-estradiol depends on ubiquitin-proteasome degradation of PPAR- $\gamma$ mediated by NEDD4-1. Protein Cell. 2013;4(4):310-21.

83. Yang $Z X$, Shen $W$, Sun $H$. Effects of nuclear receptor FXR on the regulation of liver lipid metabolism in patients with non-alcoholic fatty liver disease. Hepatol Int. 2010:4(4):741-8.

84. Jiang C, Xie C, Li F, Zhang L, Nichols RG, Krausz KW, Cai J, Qi Y, Fang ZZ, Takahashi S, Tanaka N. Intestinal farnesoid X receptor signaling promotes nonalcoholic fatty liver disease. J Clin Invest. 2015;125(1):386-402.

85. Sheng L, Jena PK, Liu HX, Kalanetra KM, Gonzalez FJ, French SW, Krishnan W, Mills DA, Wan YJ. Gender differences in bile acids and microbiota in relationship with gender dissimilarity in steatosis induced by diet and FXR inactivation. Sci Rep. 2017;7(1):1748.

86. Bennion LJ, Drobny E, Knowler WC, Ginsberg RL, Garnick MB, Adler RD, Duane WC. Sex differences in the size of bile acid pools. Metabolism. 1978;27(8):961-9

87. Baars A, Oosting A, Lohuis M, Koehorst M, El Aidy S, Hugenholtz F, Smidt H, Mischke M, Boekschoten MV, Verkade HJ, Garssen J. Sex differences in lipid metabolism are affected by presence of the gut microbiota. Sci Rep. 2018;8(1):13426.

88. Ridlon JM, Kang DJ, Hylemon PB, Bajaj JS. Bile acids and the gut microbiome. Curr Opin Gastroenterol. 2014;30(3):332.

89. Lopetuso LR, Scaldaferri F, Petito V, Gasbarrini A. Commensal Clostridia: leading players in the maintenance of gut homeostasis. Gut Pathog. 2013;5(1):23.

90. Claudel $T$, Staels $B$, Kuipers $F$. The Farnesoid $X$ receptor: a molecular link between bile acid and lipid and glucose metabolism. Arterioscler Thromb Vasc Biol. 2005;25(10):2020-30

91. Yurkovetskiy L, Burrows M, Khan AA, Graham L, Volchkov P, Becker L, Antonopoulos D, Umesaki Y, Chervonsky AV. Gender bias in autoimmunity is influenced by microbiota. Immunity. 2013;39(2):400-12.

92. Markle JG, Frank DN, Mortin-Toth S, Robertson CE, Feazel LM, RolleKampczyk U, Von Bergen M, McCoy KD, Macpherson AJ, Danska JS. Sex differences in the gut microbiome drive hormone-dependent regulation of autoimmunity. Science. 2013;339(6123):1084-8.

93. Shimizu K, Muranaka Y, Fujimura R, ISHIDA H, TAZUME S, SHIMAMURA T. Normalization of reproductive function in germfree mice following bacterial contamination. Experimental animals. 1998;47(3):151-8.
94. Martin F, Peltonen J, Laatikainen T, Pulkkinen M, Adlercreutz H. Excretion of progesteone metabolites and estriol in faeces from pregnant women during ampicillin administration. J Steroid Biochem. 1975;6(9):1339-46.

95. Adlercreutz H, Martin F, Pulkkinen M, Dencker $H$, Rimer U, Sjoberg NO, Tikkanen MJ. Intestinal metabolism of estrogens. J Clin Endocrinol Metab. 1976;43(3):497-505

96. Chen M, Cheng KW, Chen YJ, Wang CH, Cheng TC, Chang KC, Kao $\mathrm{AP}$, Chuang $\mathrm{KH}$. Real-time imaging of intestinal bacterial $\beta$ glucuronidase activity by hydrolysis of a fluorescent probe. Sci Rep. 2017;7(1):3142

97. Mclntosh FM, Maison N, Holtrop G, Young P, Stevens VJ, Ince J, Johnstone AM, Lobley GE, Flint HJ, Louis P. Phylogenetic distribution of genes encoding $\beta$-glucuronidase activity in human colonic bacteria and the impact of diet on faecal glycosidase activities. Environ Microbiol. 2012;14(8):1876-87.

98. Gloux K, Berteau O, Béguet F, Leclerc M, Doré J. A metagenomic $\beta$ glucuronidase uncovers a core adaptive function of the human intestinal microbiome. Proc Natl Acad Sci. 2011;108(Supplement 1): 4539-46.

99. Jose PA, Raj D. Gut microbiota in hypertension. Curr Opin Nephrol Hypertens. 2015;24(5):403-9.

100. Pevsner-Fischer M, Blacher E, Tatirovsky E, Ben-Dov IZ, Elinav E. The gut microbiome and hypertension. Curr Opin Nephrol Hypertens. 2017;26(1):1-8.

101. Richards EM, Pepine CJ, Raizada MK, Kim S. The gut, its microbiome, and hypertension. Curr Hypertens Rep. 2017;19(4):36.

102. Marques FZ, Mackay CR, Kaye DM. Beyond gut feelings: how the gut microbiota regulates blood pressure. Nat Rev Cardiol. 2017;15(1):20-32.

103. Yang T, Santisteban MM, Rodriguez V, Li E, Ahmari N, Carvajal JM, et al. Gut dysbiosis is linked to hypertension. Hypertension. 2015; 65(6):1331-40.

104. Li J, Zhao F, Wang Y, Chen J, Tao J, Tian G, et al. Gut microbiota dysbiosis contributes to the development of hypertension. Microbiome. 2017;5(1):14

105. Marques FZ, Nelson E, Chu P-Y, Horlock D, Fiedler A, Ziemann M, et al. High-fiber diet and acetate supplementation change the gut microbiota and prevent the development of hypertension and heart failure in hypertensive mice. Circulation. 2017;135(10):964-77.

106. Khalesi S, Sun J, Buys N, Jayasinghe R. Effect of probiotics on blood pressure. Hypertension. 2014;64(4):897-903.

107. Bartolomaeus H, Balogh A, Yakoub M, Homann S, Markó L, Höges S, et al. Short-chain fatty acid propionate protects from hypertensive cardiovascular damage. Circulation. 2019;139(11):1407-21.

108. Ahrén IL, Xu J, Önning G, Olsson C, Ahrné S, Molin G. Antihypertensive activity of blueberries fermented by Lactobacillus plantarum DSM 15313 and effects on the gut microbiota in healthy rats. Clin Nutr. 2015;34(4):719-26.

109. Seppo L, Jauhiainen T, Poussa T, Korpela R. A fermented milk high in bioactive peptides has a blood pressure-lowering effect in hypertensive subjects. Am J Clin Nutr. 2003;77(2):326-30.

110. Fuglsang A, Rattray FP, Nilsson D, Nyborg NCB. Lactic acid bacteria: inhibition of angiotensin converting enzyme in vitro and in vivo. Antonie Van Leeuwenhoek. 2003;83(1):27-34.

111. Zimmerman MA, Sullivan JC. Hypertension: what's sex got to do with it? Physiology. 2013;28(4):234-44.

112. Gillis EE, Sullivan JC. Sex differences in hypertension: recent advances Hypertension. 2016;68(6):1322-7.

113. Lezutekong JN, Nikhanj A, Oudit GY. Imbalance of gut microbiome and intestinal epithelial barrier dysfunction in cardiovascular disease. Clin Sci (Lond). 2018;132(8):901-4.

114. Ivanov II, Atarashi K, Manel N, Brodie EL, Shima T, Karaoz U, et al. Induction of intestinal Th17 cells by segmented filamentous bacteria. Cell. 2009;139(3):485-98.

115. Guzik TJ, Hoch NE, Brown KA, McCann LA, Rahman A, Dikalov S, et al. Role of the $T$ cell in the genesis of angiotensin II induced hypertension and vascular dysfunction. J Exp Med. 2007;204(10):2449-60.

116. Wenzel U, Turner JE, Krebs C, Kurts C, Harrison DG, Ehmke H. Immune mechanisms in arterial hypertension. J Am Soc Nephrol. 2016;27(3): $677-86$

117. Wilck N, Matus MG, Kearney SM, Olesen SW, Forslund K, Bartolomaeus H, et al. Salt-responsive gut commensal modulates TH17 axis and disease. Nature. 2017:551(7682):585. 
118. He J, Gu D, Chen J, Jaquish CE, Rao DC, Hixson JE, et al. Gender difference in blood pressure responses to dietary sodium intervention in the GenSalt study. J Hypertens. 2009;27(1):48-54.

119. Schiffrin EL. Immune mechanisms in hypertension and vascular injury. Clin Sci. 2014;126(4):267-74.

120. Cotillard A, Kennedy SP, Kong LC, Prifti E, Pons N, Le Chatelier E, et al. Dietary intervention impact on gut microbial gene richness. Nature. 2013; 500(7464):585-8.

121. Blasco-Baque V, Serino M, Vergnes J-N, Riant E, Loubieres P, Arnal J-F, et al. High-fat diet induces periodontitis in mice through lipopolysaccharides (LPS) receptor signaling: protective action of estrogens. Federici M, editor. PLoS One 2012;7(11):e48220.

122. Riant E, Waget A, Cogo H, Arnal J-F, Burcelin R, Gourdy P. Estrogens protect against high-fat diet-induced insulin resistance and glucose intolerance in mice. Endocrinology. 2009;150(5):2109-17.

123. Ghisletti S, Meda C, Maggi A, Vegeto E. 17beta-estradiol inhibits inflammatory gene expression by controlling NF-kappaB intracellular localization. Mol Cell Biol. 2005;25(8):2957-68.

124. Schwandner R, Dziarski R, Wesche H, Rothe M, Kirschning CJ. Peptidoglycanand lipoteichoic acid-induced cell activation is mediated by toll-like receptor 2. J Biol Chem. 1999;274(25):17406-9.

125. Org E, Mehrabian M, Parks BW, Shipkova P, Liu X, Drake TA, Lusis AJ. Sex differences and hormonal effects on gut microbiota composition in mice. Gut microbes. 2016;79(4):313-22.

126. Furness JB, Rivera LR, Cho H-J, Bravo DM, Callaghan B. The gut as a sensory organ. Nat Rev Gastroenterol Hepatol. 2013;1010(1212):729-40.

127. Chambers ES, Preston T, Frost G, Morrison DJ. Role of gut microbiotagenerated short-chain fatty acids in metabolic and cardiovascular health. Current nutrition reports. 2019;7(4):198-206.

128. Pluznick J. A novel SCFA receptor, the microbiota, and blood pressure regulation. Gut Microbes. 2014;5(2):202-7.

129. Pluznick JL, Protzko RJ, Gevorgyan H, Peterlin Z, Sipos A, Han J, et al. Olfactory receptor responding to gut microbiota-derived signals plays a role in renin secretion and blood pressure regulation. Proc Natl Acad Sci. 2013;110(11):4410-5.

130. Ivy JR, Bailey MA. Pressure natriuresis and the renal control of arterial blood pressure. J Physiol. 2014;592(18):3955-67.

131. Hall JE. Renal dysfunction, rather than nonrenal vascular dysfunction, mediates salt-induced hypertension. Circulation. 2016;133(9):894-906.

132. Menni C, Lin C, Cecelja M, Mangino M, Matey-Hernandez ML, Keehn L, et al. Gut microbial diversity is associated with lower arterial stiffness in women. Eur Heart J. 2018;39(25):2390-7.

133. Turnbaugh PJ, Ley RE, Mahowald MA, Magrini V, Mardis ER, Gordon Jl. An obesity-associated gut microbiome with increased capacity for energy harvest. Nature. 2006;444(7122):1027-31.

134. Kimura I, Inoue D, Maeda T, Hara T, Ichimura A, Miyauchi S, et al. Shortchain fatty acids and ketones directly regulate sympathetic nervous system via G protein-coupled receptor 41 (GPR41). Proc Natl Acad Sci. 2011;108(19):8030-5

135. Million M, Maraninchi $M$, Henry M, Armougom F, Richet $H$, Carrieri $P$, et al Obesity-associated gut microbiota is enriched in Lactobacillus reuteri and depleted in Bifidobacterium animalis and Methanobrevibacter smithii. Int J Obes. 2012;36(6):817-25.

136. Ley RE, Turnbaugh PJ, Klein S, Gordon Jl. Human gut microbes associated with obesity. Nature. 2006;444(7122):1022-3.

137. David LA, Maurice CF, Carmody RN, Gootenberg DB, Button JE, Wolfe BE, et al. Diet rapidly and reproducibly alters the human gut microbiome. Nature. 2014;505(7484):559-63.

138. Wu GD, Chen J, Hoffmann C, Bittinger K, Chen Y-Y, Keilbaugh SA, et al. Linking long-term dietary patterns with gut microbial enterotypes. Science. 2011;334(6052):105-8.

139. Kovatcheva-Datchary P, Nilsson A, Akrami R, Lee YS, De Vadder F, Arora T, et al. Dietary fiber-induced improvement in glucose metabolism is associated with increased abundance of Prevotella. Cell Metab. 2015;22(6):971-82.

140. Walker AW, Ince J, Duncan SH, Webster LM, Holtrop G, Ze X, et al. Dominant and diet-responsive groups of bacteria within the human colonic microbiota. ISME J. 2011;5(2):220-30.

141. Ley RE, Hamady M, Lozupone C, Turnbaugh PJ, Ramey RR, Bircher JS, et al. Evolution of mammals and their gut microbes. Science. 2008;320(5883):1647-51.

142. Muegge BD, Kuczynski J, Knights D, Clemente JC, Gonzalez A, Fontana L, et al. Diet drives convergence in gut microbiome functions across mammalian phylogeny and within humans. Science. 2011;332(6032):970-4.
143. Sonnenburg $\lrcorner$, Bäckhed F. Diet-microbiota interactions as moderators of human metabolism. Nature. 2016;535(7610):56-64.

144. Wexler AG, Goodman AL. An insider's perspective: Bacteroides as a window into the microbiome. Nat. Microbiol. 2017;2(5):17026.

145. Hersoug L-G, Møller P, Loft S. Gut microbiota-derived lipopolysaccharide uptake and trafficking to adipose tissue: implications for inflammation and obesity. Obes Rev. 2016;17(4):297-312.

146. Chassaing B, Koren O, Goodrich JK, Poole AC, Srinivasan S, Ley RE, et al. Dietary emulsifiers impact the mouse gut microbiota promoting colitis and metabolic syndrome. Nature. 2015;519(7541):92-6.

147. Koren O, Goodrich JK, Cullender TC, Spor A, Laitinen K, Kling Bäckhed H, et al. Host remodeling of the gut microbiome and metabolic changes during pregnancy. Cell. 2012;150(3):470-80.

148. Al-Assal K, Martinez AC, Torrinhas RS, Cardinelli C, Waitzberg D. Gut microbiota and obesity. Clin Nutr Exp. 2018;20:60-4.

149. Backhed F, Ding H, Wang T, Hooper LV, Koh GY, Nagy A, et al. The gut microbiota as an environmental factor that regulates fat storage. Proc Nat Acad Sci. 2004;101(44):15718-23.

150. Jiang $Z$, Huang $X$, Huang $S$, Guo H, Wang L, Li X, et al. Sex-related differences of lipid metabolism induced by triptolide: the possible role of the LXRa/SREBP-1 signaling pathway. Front Pharmacol. 2016;7:87.

151. Khan MJ, Gerasimidis K, Edwards CA, Shaikh MG. Role of gut microbiota in the aetiology of obesity: proposed mechanisms and review of the literature. J Obes. 2016;2016:1-27.

152. Kimura I, Ozawa K, Inoue D, Imamura T, Kimura K, Maeda T, et al. The gut microbiota suppresses insulin-mediated fat accumulation via the short-chain fatty acid receptor GPR43. Nat Commun. 2013;4(1):1829.

153. Cani PD, Possemiers S, Van de Wiele T, Guiot Y, Everard A, Rottier O, et al. Changes in gut microbiota control inflammation in obese mice through a mechanism involving GLP-2-driven improvement of gut permeability. Gut. 2009;58(8):1091-103

154. Geurts L, Lazarevic V, Derrien M, Everard A, Van Roye M, Knauf C, et al. Altered gut microbiota and endocannabinoid system tone in obese and diabetic leptin-resistant mice: impact on apelin regulation in adipose tissue. Front Microbiol. 2011;2:149.

155. Inoue D, Tsujimoto G, Kimura I. Regulation of energy homeostasis by GPR41. Front Endocrinol (Lausanne). 2014;5:81.

156. Bellahcene M, O'Dowd JF, Wargent ET, Zaibi MS, Hislop DC, Ngala RA, et al. Male mice that lack the G-protein-coupled receptor GPR41 have low energy expenditure and increased body fat content. $\mathrm{Br} J$ Nutr. 2013;109(10):1755-64.

157. Canfora EE, Blaak EE. Acetate: a diet-derived key metabolite in energy metabolism: good or bad in context of obesity and glucose homeostasis? Curr Opin Clin Nutr Metab Care. 2017;20(6):477-83.

158. Frost G, Sleeth ML, Sahuri-Arisoylu M, Lizarbe B, Cerdan S, Brody L, et al. The short-chain fatty acid acetate reduces appetite via a central homeostatic mechanism. Nat Commun. 2014:5(1):3611

159. Sahuri-Arisoylu M, Brody LP, Parkinson JR, Parkes H, Navaratnam N, Miller AD, et al. Reprogramming of hepatic fat accumulation and "browning" of adipose tissue by the short-chain fatty acid acetate. Int J Obes. 2016;40(6):955-63.

160. Brooks L, Viardot A, Tsakmaki A, Stolarczyk E, Howard JK, Cani PD, et al. Fermentable carbohydrate stimulates FFAR2-dependent colonic PYY cell expansion to increase satiety. Mol Metab. 2017;6(1):48-60.

161. Li X, Chen H, Guan Y, Li X, Lei L, Liu J, et al. Acetic acid activates the AMPactivated protein kinase signaling pathway to regulate lipid metabolism in bovine hepatocytes. Zang M, editor. PLoS One 2013;8(7):e67880.

162. Everard A, Lazarevic V, Gaïa N, Johansson M, Ståhlman M, Backhed F, et al. Microbiome of prebiotic-treated mice reveals novel targets involved in host response during obesity. ISME J. 2014;8(10):2116-30.

163. Lu Y, Fan C, Li P, Lu Y, Chang X, Qi K. Short chain fatty acids prevent highfat-diet-induced obesity in mice by regulating $G$ protein-coupled receptors and gut microbiota. Sci Rep. 2016;6(1):37589.

164. McNelis JC, Lee YS, Mayoral R, van der Kant R, Johnson AMF, Wollam J, et al. GPR43 potentiates $\beta$-cell function in obesity. Diabetes. 2015;64(9):3203-17.

165. Fernandes J, Vogt J, Wolever TM. Intravenous acetate elicits a greater free fatty acid rebound in normal than hyperinsulinaemic humans. Eur J Clin Nutr. 2012;66(9):1029.

166. van der Beek CM, Canfora EE, Lenaerts K, Troost FJ, Damink SWMO, Holst JJ, et al. Distal, not proximal, colonic acetate infusions promote fat oxidation and improve metabolic markers in overweight/obese men. Clin Sci. 2016;130(22):2073-82. 
167. Priyadarshini M, Villa SR, Fuller M, Wicksteed B, Mackay CR, Alquier T, et al. An acetate-specific GPCR, FFAR2, regulates insulin secretion. Mol Endocrinol. 2015;29(7):1055-66.

168. Canfora EE, van der Beek CM, Jocken JWE, Goossens GH, Holst JJ, Olde Damink SWM, et al. Colonic infusions of short-chain fatty acid mixtures promote energy metabolism in overweight/obese men: a randomized crossover trial. Sci Rep. 2017;7(1):2360.

169. Lim J, Henry CJ, Haldar S. Vinegar as a functional ingredient to improve postprandial glycemic control-human intervention findings and molecular mechanisms. Mol Nutr Food Res. 2016;60(8):1837-49.

170. Perry RJ, Peng L, Barry NA, Cline GW, Zhang D, Cardone RL, et al. Acetate mediates a microbiome-brain- $\beta$-cell axis to promote metabolic syndrome. Nature. 2016;534(7606):213-7

171. Tang C, Ahmed K, Gille A, Lu S, Gröne H-J, Tunaru S, et al. Loss of FFA2 and FFA3 increases insulin secretion and improves glucose tolerance in type 2 diabetes. Nat Med. 2015;21(2):173-7.

172. Moran A, Jacobs DR, Steinberger J, Steffen LM, Pankow JS, Hong CP, et al. Changes in insulin resistance and cardiovascular risk during adolescence: establishment of differential risk in males and females. Circulation. 2008;117(18):2361-8.

173. Tara MD, Souza SC, Aronovitz M, Obin MS, Fried SK, Greenberg AS. Estrogen regulation of adiposity and fuel partitioning evidence of genomic and nongenomic regulation of lipogenic and oxidative pathways. J Biol Chem. 2005; 280(43):35983-91.

174. Matute ML, Kalkhoff RK. Sex steroid influence on hepatic gluconeogenesis and glycogen formation. J Lab Clin Med. 1971;78(6):997-8.

175. Gupte AA, Pownall HJ, Hamilton DJ. Estrogen: an emerging regulator of insulin action and mitochondrial function. J Diabetes Res. 2015;2015:916585.

176. Patel P, Abate N. Body fat distribution and insulin resistance. Nutrients. 2013; 5(6):2019-27.

177. Ma H, Tam QT, Kolattukudy PE. Peroxisome proliferator-activated receptor Y1 (PPAR- $\gamma 1)$ as a major PPAR in a tissue in which estrogen induces peroxisome proliferation. Febs Lett. 1998;434(3):394-400.

178. Geer EB, Shen W. Gender differences in insulin resistance, body composition, and energy balance. Gend Med. 2009;6:60-75

179. Polderman KH, Gooren $\amalg$, Asscheman HE, Bakker AB, Heine RJ. Induction of insulin resistance by androgens and estrogens. J Clin Endocrinol Metab. 1994;79(1):265-71.

180. Moghetti PA, Tosi FL, Castello RO, Magnani CM, Negri CA, Brun E, Furlani L, Caputo MA, Muggeo Ml. The insulin resistance in women with hyperandrogenism is partially reversed by antiandrogen treatment: evidence that androgens impair insulin action in women. J Clin Endocrinol Metab. 1996;81(3):952-60.

181. Perello M, Castrogiovanni D, Giovambattista A, Gaillard RC, Spinedi E. Impairment in insulin sensitivity after early androgenization in the post-pubertal female rat. Life Sci. 2007;80(19):1792-8.

182. Mårin $P$, Holmäng $S$, Jönsson L, Sjöström L, Kvist H, Holm G, Lindstedt G, Björntorp P. The effects of testosterone treatment on body composition and metabolism in middle-aged obese men. Int $J$ Obes Relat Metab Disord. 1992;16(12):991-7.

183. Rebuffe-Scrive M, Mårin P, Björntorp P. Effect of testosterone on abdominal adipose tissue in men. Int J Obes. 1991;15(11):791-5.

184. Abbott RD, Garrison RJ, Wilson PW, Epstein FH, Castelli WP, Feinleib M, LaRue C. Joint distribution of lipoprotein cholesterol classes. The Framingham study. Arteriosclerosis. 1983;3(3):260-72.

185. Magkos F, Mittendorfer B. Gender differences in lipid metabolism and the effect of obesity. Obstet Gynecol Clin N Am. 2009:36(2):245-65.

186. Palmisano BT, Zhu L, Eckel RH, Stafford JM. Sex differences in lipid and lipoprotein metabolism. Mol Metab. 2018;15:45.

187. Vaidya D, Dobs A, Gapstur SM, Golden SH, Hankinson A, Liu K, Ouyang $P$. The association of endogenous sex hormones with lipoprotein subfraction profile in the Multi-Ethnic Study of Atherosclerosis. Metabolism. 2008;57(6):782-90.

188. Martins D, Nelson K, Pan D, Tareen N, Norris K. The effect of gender on age-related blood pressure changes and the prevalence of isolated systolic hypertension among older adults: data from NHANES III. J Gend Specif Med. 2001;4(3):10-3, 20

189. Benza RL, Miller DP, Gomberg-Maitland M, Frantz RP, Foreman AJ, Coffey $C S$, et al. Predicting survival in pulmonary arterial hypertension. Circulation. 2010;122(2):164-72
190. Fryar CD, Ostchega Y, Hales CM, Zhang G, Kruszon-Moran D. "Hypertension Prevalence and Control Among Adults: United States, 2015-2016." NCHS Data Brief. 2017;(289):1-8.

191. Cadeddu C, Franconi F, Cassisa L, Campesi I, Pepe A, Cugusi L, Maffei S, Gallina S, Sciomer S, Mercuro G. Arterial hypertension in the female world: pathophysiology and therapy. J Cardiovasc Med. 2016;17(4):229-36

192. Colafella KMM, Denton KM. Sex-specific differences in hypertension and associated cardiovascular disease. Nat Rev Nephrol. 2018;14(3):185.

193. Yang X-P, Reckelhoff JF. Estrogen, hormonal replacement therapy and cardiovascular disease. Curr Opin Nephrol Hypertens. 2011;20(2):133-8.

194. Nevzati E, Shafighi M, Bakhtian KD, Treiber H, Fandino J, Fathi AR. Estrogen induces nitric oxide production via nitric oxide synthase activation in endothelial cells. In: Neurovascular Events After Subarachnoid Hemorrhage. Cham: Springer; 2015. p. 141-5.

195. Hales CM, Carroll MD, Fryar CD, Ogden CL. Prevalence of obesity among adults and youth: United States, 2015-2016; 2017.

196. Wells JCK. Sexual dimorphism of body composition. Best Pract Res Clin Endocrinol Metab. 2007;21(3):415-30.

197. Taylor RW, Grant AM, Williams SM, Goulding A. Sex differences in regional body fat distribution from pre- to postpuberty. Obesity. 2010;18(7):1410-6.

198. Shi H, Seeley RJ, Clegg DJ. Sexual differences in the control of energy homeostasis. Front Neuroendocrinol. 2009;30(3):396-404.

199. Brown LM, Clegg DJ. Central effects of estradiol in the regulation of food intake, body weight, and adiposity. J Steroid Biochem Mol Biol. 2010;122(1-3):65-73.

\section{Publisher's Note}

Springer Nature remains neutral with regard to jurisdictional claims in published maps and institutional affiliations.

Ready to submit your research? Choose BMC and benefit from:

- fast, convenient online submission

- thorough peer review by experienced researchers in your field

- rapid publication on acceptance

- support for research data, including large and complex data types

- gold Open Access which fosters wider collaboration and increased citations

- maximum visibility for your research: over $100 \mathrm{M}$ website views per year

At $\mathrm{BMC}$, research is always in progress.

Learn more biomedcentral.com/submissions 